\title{
Calcium intake and cows' milk free diets
}

\author{
J DEVLIN, R H J STANTON, AND T J DAVID \\ Department of Child Health, University of Manchester
}

SUMMARY In children with atopic eczema on elimination diets, the calcium intake was below the estimated requirement in 15 out of 20 who avoided cows' milk and received no milk substitute, and in three out of 26 who avoided cows' milk but were provided with a soya or casein hydrolysate formula.

Intolerance to food is sometimes suspected in children with eczema and other atopic diseases, and such children are frequently treated with a diet which excludes cows' milk. As dairy products are the major dietary source of calcium, a milk substitute based on soya or casein hydrolysate formula is usually advised to ensure an adequate intake of calcium.

The question arises as to whether in practice adequate calcium intakes are achieved in children on cows' milk free diets. In order to assess whether children on elimination diets are receiving an adequate intake of nutrients, we have used dietary surveys to examine their calcium and vitamin D intake.

\section{Patients and methods}

Between 1981 and 1987, 56 diet surveys were performed on 48 children between the age of 8 months and 14 years. All were patients with atopic eczema attending our outpatient department. All had been treated with a 'few food' or elemental diet. In the 'few food' diet the patient was allowed only six foods (for example, lamb, potato, rice, rice crispies, pears, and water) for a six week period. In the elemental diet the patient's intake consisted solely of an elemental formula (Vivonex, Norwich Eaton Laboratories) for four weeks. At the end of either period the diet was abandoned if there had not been substantial improvement in the eczema. If the eczema improved, then single food items were reintroduced at the rate of one per week with the aim of identifying foods which worsened the eczema. After three months of reintroductions, a diet survey was routinely performed to assess the nutritional adequacy of the child's diet. In eight patients the child remained on a very restricted diet for more than six months, so a diet survey was repeated. To perform a diet survey, the parents were asked to record, using household measures, all food and drink consumed during a five day period. From each record, estimated weights of food were used to calculate nutrient intake, using standard British food tables ${ }^{1}$ and manufacturers' data. Before August 1983 this was done using a electronic calculator. Thereafter the task was performed using the Salford University 'Microdiet' programme on a microcomputer.

For this study, the patients were allocated to three groups. These were group 1: those taking cows' milk and other cows' milk products, but with other dietary restrictions; group 2: those on a cows' milk free diet and other dietary restrictions, but taking a cows' milk substitute (Wysoy (Wyeth) a soya-based formula or Pregestimil (Mead Johnson), a casein hydrolysate milk formula, or goats' milk); group 3: those on a cows' milk free diet and other dietary restrictions but taking no cows' milk substitute.

Royer noted that the adult human skeleton contains approximately $1 \mathrm{~kg}$ of calcium more than that of the newborn. ${ }^{2}$ The average accretion rate from birth to 18 years is therefore around $150 \mathrm{mg}$ per day. This is higher at times of rapid somatic growth, from birth to 2 years and during puberty..$^{2-4}$ Assuming an obligatory urine loss of one to six mg per day and a maximal calcium absorption from the gut of around $60 \%,{ }^{2}$ the minimum daily intake which will ensure normal skeletal mineralisation at different ages can be calculated and is shown in the table. The calcium requirements shown in the table were chosen as cut off points for a low calcium intake in the present study. A low intake of vitamin $D$ was arbitrarily defined as less than $1 \mu \mathrm{g}$ per day.

\section{Results}

The children on a diet including cows' milk (group 1) were found to have a mean calcium intake of 792 mg/day (range 431-1021). Those using a cows' milk substitute (group 2) had a mean intake of 413 $\mathrm{mg} /$ day (range 164-797), and the children in group 3 , taking neither cows' milk nor a milk substitute, 
Table Calcium accretion rate and requirements by age and number of patients with intake below age related requirements

\begin{tabular}{|c|c|c|c|c|c|}
\hline \multirow[t]{2}{*}{$\begin{array}{l}\text { Age } \\
\text { (years) }\end{array}$} & \multirow{2}{*}{$\begin{array}{l}\text { Accretion } \\
\text { rate }^{2-4} \\
\text { (mg/day) }\end{array}$} & \multirow{2}{*}{$\begin{array}{l}\text { Approximate } \\
\text { requirements } \\
\text { (mg/day) }\end{array}$} & \multicolumn{3}{|c|}{$\begin{array}{l}\text { No below requirements } \\
\text { for age group }\end{array}$} \\
\hline & & & Group 1 & Group 2 & Group 3 \\
\hline $0-1$ & 190 & 300 & $0 / 2$ & $2 / 6$ & $3 / 5$ \\
\hline $2-7$ & 70 & 150 & $0 / 3$ & $0 / 18$ & $2 / 12$ \\
\hline $8-10$ & 140 & 250 & - & $1 / 2$ & $3 / 3$ \\
\hline $11-18$ & 250 & 500 & $1 / 5$ & - & - \\
\hline Total & & & $1 / 10$ & $3 / 26$ & $8 / 20$ \\
\hline
\end{tabular}

Group 1: taking cows' milk, group 2: on milk free diet plus a milk substitute, group 3: on milk free diet with no milk substitute.

had a mean calcium intake of $213 \mathrm{mg} /$ day (range 123-444). The calcium intakes in the three groups were significantly different $(\mathrm{p}<0 \cdot 005$, Wilcoxon rank sum test).

When the calcium intake was compared with the age related requirements, however, it was found (see table) that most children studied were aged 2 to 7 years, when calcium requirements are relatively low. Thus only three of the 26 patients receiving milk substitutes had an intake lower than their requirements, while eight of 20 who were not receiving milk or a milk substitute had an intake lower than their requirements.

In the children in group 1 , the mean contribution of milk to the daily calcium intake was $405 \mathrm{mg}$ $(51 \%)$, and a further $146 \mathrm{mg}(18 \%)$ was derived from milk products such as cheese. A milk substitute contributed a mean of $229 \mathrm{mg}(55 \%)$ to the daily calcium intake of the children in group 2.

The daily vitamin $D$ intake was less than $1 \mu \mathrm{g}$ in three out of 10 patients in group 1 , seven out of 26 in group 2, and 15 out of 20 in group 3.

\section{Discussion}

This study shows that it is unsafe to assume that calcium requirements will be adequately provided by the prescription of a cows' milk substitute in children on a diet excluding cows' milk. The need for calcium supplements in such patients will depend on the calcium content of the remaining diet, the age of the child, and the nature of the disease being treated. In children with atopic eczema, there are three special circumstances which may increase the need for calcium. Firstly, intestinal absorption of calcium may be impaired in eczematous children who have an enteropathy. ${ }^{5}$ Secondly, the absence of lactose in the diet may reduce calcium absorption. ${ }^{6}$ Finally, there is a risk of vitamin D deficiency and consequently diminished gastrointestinal calcium absorption in children with atopic eczema who are kept out of sunlight.

We thank Dr MZ Mughal and Dr J Couriel for their helpful comments. JD is supported by the National Eczema Society.

\section{References}

1 Paul AA, Southgate DAT. McCance and Widdowson's The composition of foods. Fourth revised and extended edition of MRC Special Report No 297. London: HMSO, 1978.

${ }^{2}$ Royer P. Growth and development of bony tissues. In: Davis JA, Dobbing J. eds. Scientific foundations of paediatrics. 2nd ed. London: Heinemann, 1981:565-89.

${ }^{3}$ Ziegler EE, Fomon SJ. Major minerals. In: Fomon SJ, ed. Infant nutrition. 2nd ed. Philadelphia: WB Saunders, 1974:267-97.

${ }^{4}$ Leitch I, Aitken FC. The estimation of calcium requirement: a re-examination. Nutrition Abstracts and Reviews 1959;29: 393-411.

5 Walker-Smith J, Harrison M, Kilby A, Phillips A, France N. Cows' milk sensitive enteropathy. Arch Dis Child 1978;53: 375-80.

6 Zeigler EE, Fomon SJ. Lactose enhances mineral absorption in infancy. J Pediatr Gastroenterol Nutr 1983;2:288-94.

Correspondence to Dr TJ David, Booth Hall Children's Hospital, Charlestown Road, Blackley, Manchester M9 2AA.

Accepted 10 February 1989 